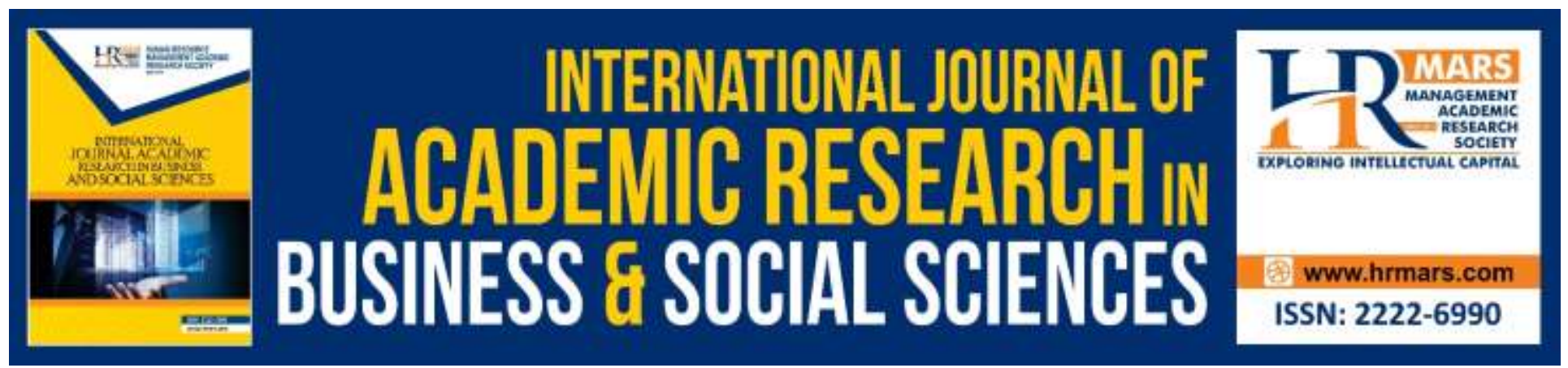

\title{
Relationship Between Concentrations of Foreign Trade and Financial Performance: An Application in Drug Sector in Turkey
}

\section{Evren Ayranci, Cigdem Erdin}

To Link this Article: http://dx.doi.org/10.6007/IJARBSS/v10-i2/7002

DOI:10.6007/IJARBSS/v10-i2/7002

Received: 20 January 2020, Revised: 01 February 2020, Accepted: 12 February 2020

Published Online: 29 February 2020

In-Text Citation: (Ayranci \& Erdin, 2020)

To Cite this Article: Ayranci, E., \& Erdin, Ç. (2020). Relationship Between Concentrations of Foreign Trade and Financial Performance: An Application in Drug Sector in Turkey. International Journal of Academic Research in Business and Social Sciences, 10(2), 758-772.

Copyright: (C) 2020 The Author(s)

Published by Human Resource Management Academic Research Society (www.hrmars.com)

This article is published under the Creative Commons Attribution (CC BY 4.0) license. Anyone may reproduce, distribute, translate and create derivative works of this article (for both commercial and non-commercial purposes), subject to full attribution to the original publication and authors. The full terms of this license may be seen at: http://creativecommons.org/licences/by/4.0/legalcode

\section{Vol. 10, No. 2, 2020, Pg. 758 - 772}

Full Terms \& Conditions of access and use can be found at http://hrmars.com/index.php/pages/detail/publication-ethics 


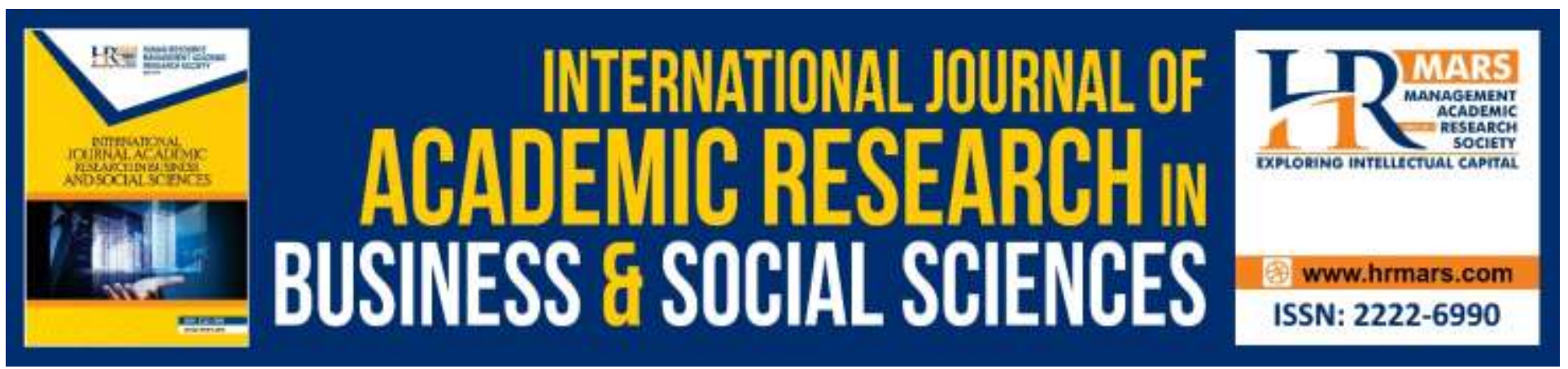

\title{
Relationship Between Concentrations of Foreign Trade and Financial Performance: An Application in Drug Sector in Turkey
}

\author{
Evren Ayranci ${ }^{1}$, Çiğdem Erdin ${ }^{2}$ \\ ${ }^{1}$ Istanbul Kultur University, Faculty of Economics and Administrative Sciences, Istanbul, Turkey. \\ ${ }^{2}$ Istanbul AREL University, Institute of Social Sciences, Istanbul, Turkey.
}

\begin{abstract}
This study investigates possible connections between two performance ends - foreign trade and financial performance - of a leading drug company in Turkey within January 2014-December 2018 period. A unique approach is that these two are not under the spotlights directly, in other words, their financial figures are not under consideration. Instead, the primary goal is to calculate each performance end's concentration index values. Put other way, this study primarily seeks to explore the extent, to which the company is able to keep its outcomes of foreign trade and financial activities steady. The main and secondary aim, in this case, is to scrutinize if and how foreign trade concentration (steadiness) is a descriptor of financial performance concentration. Due to foreign trade being an important factor of business financial performance, it is also expected that the trade's extent of steadiness should also be a determinant of the financial performance stability. For the analysis, foreign trade and real operating profits' data on a quarter-basis that belong to 2014 January2018 December period are collected. After concentration calculations of the trade and financial performance using Hirschman-Herfindahl Index ( $\mathrm{HHI}$ ) are made, analyses reveal that there are indeed some similarities and differences between the concentration index values of foreign trade and financial performance. It is, however, not much possible to state that foreign trade concentration is able to affect concentrated financial performance.
\end{abstract}

Keywords: Foreign Trade, Real Operating Profits, Concentration Index, Hirschman-Herfindahl, Turkey.

\section{Introduction}

Performance could be defined as the effort shown with the intent of a successful application as a means to the extent, to which goals are achieved or the effort that seeks to achieve specific goals in a specific period of time (Ayrancı, 2014; Oyman, 2002). With these definitions in mind, business owners and managers need performance evaluation in order to determine their businesses' position within the scope of business goals, and therefore, they are able to prepare plans to pinpoint what to 
do and how to do in the future (Akal, 2005). A proper performance evaluation, moreover, could enable a scrutinization about the extent of deviations by means of comparing predetermined goals and targets with the results obtained. Thinking in business terms, an appropriate medium for business performance evaluation would be the financial context. Thus, the performance appreciation could be made in order to reveal businesses' financial status, cost and profit centers, and competitiveness within the sector (Melwani and Sitlani, 2019). This appreciation generally benefits from the use of financial ratios and seeks to explore businesses' past trends and possible future paths, as well as to unearth current profitability, risks, and investments (Adedeji, 2014; Wang and Zhou, 2016). When the issue of trade is in domain, however, the scope of the mentioned appreciation has to enlarge and thus involve businesses' trade activities.

An appropriate way of accounting for performance of trade activities in focus is the use of trade concentration indexes (Baş, 2005; Ildırar and Kıral, 2018; Küçükkiremitçi et al., 2010). The main underlying reason for the use of these indexes is that they are actually a group of instruments that forms a homogeneity, and moreover, a unity among various trade activities with an intent of informing about businesses' trade performance (Ayrancı, 2009; Demirel, 2014; Kostakoğlu, 2015; Pehlivanoğlu and Tekçe, 2013).

Starting with the aforementioned fact, this study primarily seeks to use one of the concentration indexes, the Hirschman-Herfindahl index, in order to assess foreign trade performance of a business over its net foreign trade and to calculate the concentration of its financial performance via its real operating profits. The second goal of the study is to check and comment on the possible effects of the calculated foreign trade performance on the financial performance.

It is expected that the results obtained and suggestions made could be used to provide insight to decision makers in drug sector to determine how their businesses' foreign trade and financial performance could be concentrated and how these concentrated aspects' relationships could be used for managerial and financial decisions within this sector.

\section{A General Outlook on Financial Performance and Evaluation}

When the financial dimension is added to performance, it could be considered as the monetary results that stem from business operations, and business politics and transaction within a specific period of time (Ayrancl, 2014) with the main drive of using those results to provide benefit to as many stakeholders as possible in economic terms (Caba, 2017) or to enable further entrepreneurship activities (Ayrancl, 2018). This perspective suggests that the financial performance does not only provide a clear picture of the aforementioned financial status, cost-profit matters and competitiveness; it moreover involves a great deal of importance for possible investors, related parties, and the economy in general (Melwani and Sitlani, 2019).

While this importance urges professionals to evaluate business performance with great care, a general logic is the consideration of standardization. A determination of a specific financial performance appraisal method requires the use of same types of criteria within the process of comparison among the past and current outcomes, and future outcome expectations (Aliona, 2016). Therefore, the use of a single balance sheet or income statement is meaningless unless these are compared with their antecedents or successors (Nuhu, 2014). This standardization and comparison are generally achieved through the use of profitability, assets, return on equity, and earnings per share (Wingard and Vorster, 2001) with the aim of comprehending profitability, solvency, risks and 
investments of the business along with potential changes of the business strategy (Wang and Zhou, 2016).

The standardization is a bi-fold issue, it is not only related to what to use but it is also related to specific evaluation techniques, one of which is the use of financial ratios. These ratios are posited to be very beneficial for investments (Bhamorasathit and Katawandee, 2014) and enable multiple comparisons among the past, present, and future, businesses, industries, and overall conditions of markets (Sarkodie et al., 2015). Financial ratios are not limited to provide benefits while taking a picture of the business, they are moreover beneficial to decision-makers (Adedeji, 2014). These reasons give rise to their frequent uses by credit analysts, lenders, stock analysts, business owners, managers, and investors (Wang and Zhou, 2016). Being a very standardized and indicative instrument, the aforesaid benefits of these ratios do not solely stem from their use, but also from their interpretation (Sarkodie et al., 2015).

As could be understood, the financial ratios provide an evaluation of the financial performance itself. However, the issue of investigating the extent of financial stability and sustainability is another question. In other words, the word performance is not limited to the financial figures in this case, it is about the performance of keeping these figures stable; i.e., stabilization performance. An investigation of this kind of performance requires an alternative approach and concentration calculations are one of the best approaches that could be used.

Despite various approaches about concentration concept, a generalized definition could be that it is an output reached, when the ratios that are calculated by relating each of the specific datum with its own group of data, are weighted in a specific way (Ayrancl, 2009). An application of this general definition to business environment leads to two specific issues: competitiveness and performance. An increase in market concentration is a sign that a sole business or a small group of businesses could dominate the market, leading to substantial decreases in overall competition within the market (Yaşar et al., 2017). As expected, outcomes could be great shifts in market structure (Yaşar and Gerede, 2018) and business performance (Battal, 2014). Therefore, many actors such as businesses (Baş, 2005), governments (Krivka, 2016), and business scholars (Pehlivanoğlu and Tekçe, 2013) use concentration analyses to scrutinize competitiveness, market conditions, and performance. An investigation of research that involve concentration in relation with financial performance shows that concentration calculations are used while figuring out capital structure financial performance relationship (Gleason et al., 2000), market concentrations are considered as control variables while checking return on assets (Wang et al., 2018) and profitability growth rates (Chen and Chang, 2012), gender diversity concentration indexes are used to assess firm value as measured by Tobin's Q (Campbell and Mínguez-Vera, 2008), and family ownership concentration is claimed to affect family firms' return on assets and return on equity (Minichilli et al., 2016).

\section{Concentration in Foreign Trade}

Defined as the monetary returns of international transfers of goods and services (Kaya, 2015), foreign trade is a vital aspect of reducing poverty and boosting sustainable economic growth (Boddin et al., 2017). Foreign trade enables interactions among many nations, and therefore, plays an undeniable role in promoting economic globalization (Ayrancl, 2009). The literature reveals that foreign trade concentration analyses are generally performed at sector and country levels (Ayrancl, 2009; Pindyuk, 2008) in order to find out variabilities in and dominance of relevant sectors, countries, 
or commodities exchanged. In other words, foreign trade concentration is usually regarded as the extent, to which one or more specific sectors, countries, or commodities excel in foreign trade in comparison to others. Despite this common approach, it is considered that foreign trade performance is an indispensable part of business financial performance (Yahaya et al., 2017), and thus, its concentration should also be related to the financial performance concentration.

Though there are many approaches to calculate the aforementioned financial performance and foreign trade concentrations (e.g., Ayrancı, 2009; Fosu, 2013; Alzgool, 2019; Muhammad, Saoula, Issa \& Ahmed, 2019), a very popular method is the Hirschman-Herfindahl Index (HHI). This index accounts for the relative size of each unit considered as well as the overall number of all units to calculate concentration in a given context (Roj, 2016). Its formula in equation 1 reveals that this approach priorities the share of each unit in a given wholeness (Ayrancl, 2009):

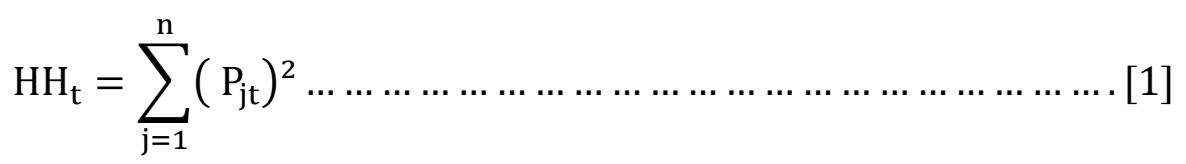

Equation 1 simply points out that the share of each unit $\mathrm{j}$ in the overall wholeness at time $t$ (Pjt) is squared (weighted by itself) and the sum of these weighted figures is calculated in order to arrive at the index value at time t. While a specific value signifies the concentration in a given time, index values at different times could be used to reveal the overall concentration trend as well as trend changes over time.

Due to its simplicity and handiness, $\mathrm{HHI}$ is frequently used for competitiveness (Evren and Bayer, 2018; Ildırar and Kıral, 2018; Kaynak, 2016; Krivka, 2016; Khalid, Islam \& Ahmed, 2019) and foreign trade concentrations (Ayrancı, 2009; Jank et al., 1999; Küçükkiremitçi et al., 2010). It is also an important agent of business financial performance concentration calculation (Clement et al., 1997; Tennyson and Fottler, 2000).

\section{Methodology}

\section{Aim, Scope and Model of Research}

The main aim of this research is to investigate and comment on the possible effects of foreign trade performance on financial performance when a leading drug company in Turkey is considered. While foreign trade performance is proxied by the company's net foreign trade figures, financial performance depends on its real operating profits. Due to the use of different currencies simultaneously, both performance ends are standardized using the $\mathrm{HHI}$ before scrutinizing the possible relationship. The use of the aforementioned index, moreover, enables to figure out the trends of both performance ends.

According to Turkish regulations, real operating profits or losses must entirely be related to the main marketable products of businesses; and thus, the drugs produced and ready to be sold in this particular case. This necessitates an exact and reciprocal match when the issue is net foreign trade. To arrive at this match, financial figures of foreign trade related to drugs such as finished drugs, drug raw materials, gelatine capsules, drug bottles, bootle caps, drug boxes, and filters, plugs, droppers and tubes within drug boxes are all accounted for the overall composition of foreign trade. 
INTERNATIONAL JOURNAL OF ACADEMIC RESEARCH IN BUSINESS AND SOCIAL SCIENCES Vol. 10, No. 2, Feb, 2020, E-ISSN: 2222-6990 @ 2020 HRMARS

Finally, the calculated import figures are deducted from the calculated export figures in order to arrive at net foreign trade.

Due to permissions of the company, all needed data are collected from its accounting and finance departments. The data are provided on a quarter-basis and belong to 2014 January-2018 December period. The main aim of the research, accompanied by the notion of concentration, gives rise to research model proposed in Figure 1.

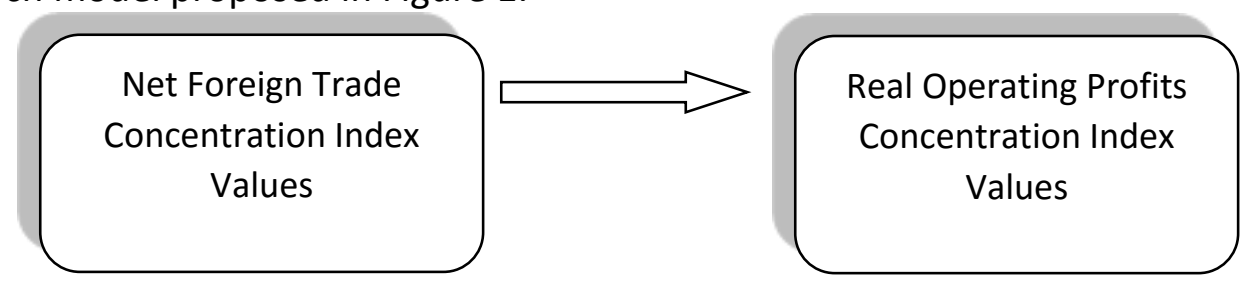

Figure 1. Research Model

\section{Concentration Trends}

The first concentration calculations belong to net foreign trade. As aforementioned, $\mathrm{HHI}$ values are calculated using the quarterly data for the 2014-2018 period; the results are given in Table 1. 
INTERNATIONAL JOURNAL OF ACADEMIC RESEARCH IN BUSINESS AND SOCIAL SCIENCES Vol. 10, No. 2, Feb, 2020, E-ISSN: 2222-6990 @ 2020 HRMARS

Table 1. Net Foreign Trade Concentration Index Values

\begin{tabular}{|c|c|c|c|c|}
\hline Year & Period & \begin{tabular}{|lr} 
Netrareign & Foreign \\
Trade HHI Value
\end{tabular} & $\begin{array}{l}\text { Annual Mean of } \\
\text { HHI Values }\end{array}$ & $\begin{array}{l}\text { Annual Standart } \\
\text { Deviation of } \mathrm{HHI} \\
\text { Values }\end{array}$ \\
\hline \multirow{4}{*}{2014} & 1 & 0.02599 & \multirow{4}{*}{0.06536} & \multirow{4}{*}{0.02801} \\
\hline & 2 & 0.06585 & & \\
\hline & 3 & 0.07996 & & \\
\hline & 4 & 0.08965 & & \\
\hline \multirow{4}{*}{2015} & 1 & 0.05977 & \multirow{4}{*}{0.06350} & \multirow{4}{*}{0.01925} \\
\hline & 2 & 0.04753 & & \\
\hline & 3 & 0.09136 & & \\
\hline & 4 & 0.05535 & & \\
\hline \multirow{4}{*}{2016} & 1 & 0.13770 & \multirow{4}{*}{0.07063} & \multirow{4}{*}{0.05101} \\
\hline & 2 & 0.06308 & & \\
\hline & 3 & 0.06806 & & \\
\hline & 4 & 0.01366 & & \\
\hline \multirow{4}{*}{2017} & 1 & 0.04803 & \multirow{4}{*}{0.06339} & \multirow{4}{*}{0.01777} \\
\hline & 2 & 0.06533 & & \\
\hline & 3 & 0.08766 & & \\
\hline & 4 & 0.05252 & & \\
\hline \multirow{4}{*}{2018} & 1 & 0.11602 & \multirow{4}{*}{0.08817} & \multirow{4}{*}{0.06527} \\
\hline & 2 & 0.15353 & & \\
\hline & 3 & 0.08274 & & \\
\hline & 4 & 0.00040 & & \\
\hline
\end{tabular}

An overall outcome from Table 1 is that the company's net foreign trade concentration varies between 0.00040 and 0.15353 , and it is also catchy that both of these two extremes are achieved in the same year, 2018. This year is also noteworthy as its first three quarters signify a great extent of a steady engagement in foreign trade, whereas the last quarter shows a vast drop in this steadiness.

It is, moreover, possible to conclude that similar drops on a smaller scale could be seen when the last quarters of most of the other years are checked, suggesting that the company could also be acting with a heavy consideration for the accounting period (calendar year) end along with possible issues such as volatilities in currencies, demand, and production capabilities in relation to foreign trade. Another implication is that the company is involved in a similar level of net foreign trade steadiness on an anuual basis except for 2016 and especially 2018. A discomposition of index values' volatilities reveals a very paralel outcome; net foreign trade concentration shows similar levels of dispersion annually albeit it rises sharply in 2016 and even further in 2018. The last two outcomes lead to conclusion that the years 2016 and 2018 could pose tremendous effects on the company's foreign trade activities. 
INTERNATIONAL JOURNAL OF ACADEMIC RESEARCH IN BUSINESS AND SOCIAL SCIENCES Vol. 10, No. 2, Feb, 2020, E-ISSN: 2222-6990 ¿ 2020 HRMARS

The next investigation is about the trend of net foreign trade concentration and Figure 2 notes that the company is diverging from this concentration when the entire period is taken into account.

Figure 2. Net Foreign Trade Concentration Trend

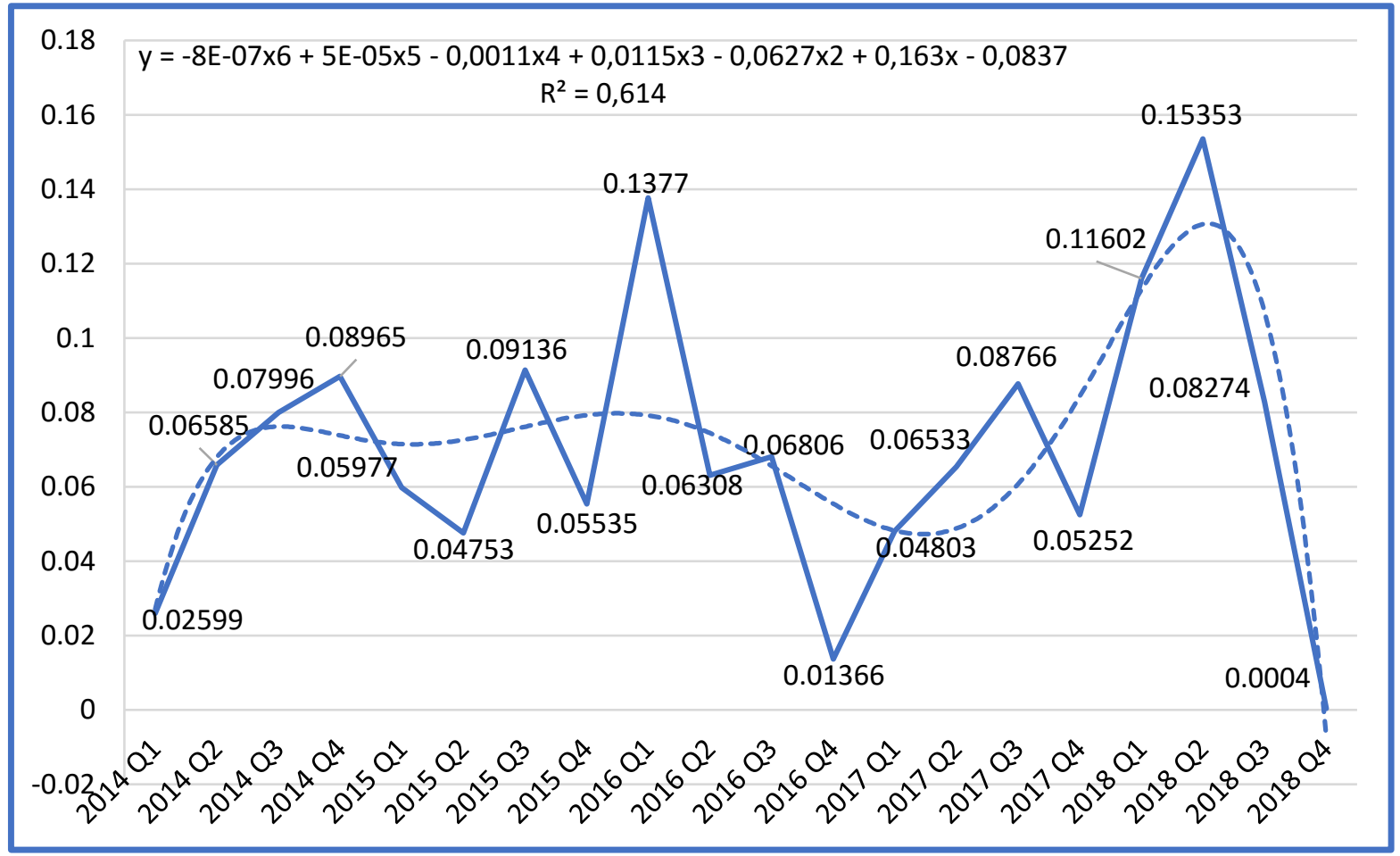

Figure 2 also reveals that the overall foreign trade concentration is subject to greater volatilities after 2015 and that the greatest changes occur in 2018. The ultimate conclusion reached after checking Table 1 and Figure 2 together is that the company has a hard time to keep directing its foreign trade activities steady in the 2016-2018 period.

The next concentration calculations are related to the company's real operating profits and Table 2 indicates that the company is more successful at keeping its average real operating profits steady on an annual basis than its ability to stabilize net foreign trade on the same basis (Table 1). A simultaneous look on the dispersions of both ends (Tables 1 and 2) acknowledge this situation as well. An implication could be that the real operating profits are achieved by both national and international activities, and thus, they could be less prone to unexpected effects or specific risks of foreign contexts in comparison to foreign trade activities. 
INTERNATIONAL JOURNAL OF ACADEMIC RESEARCH IN BUSINESS AND SOCIAL SCIENCES Vol. 10, No. 2, Feb, 2020, E-ISSN: 2222-6990 ¿ 2020 HRMARS

Table 2. Real Operating Profits Concentration Index Values

\begin{tabular}{|c|c|c|c|c|}
\hline Year & Period & $\begin{array}{l}\text { Real Operating } \\
\text { Profits HHI } \\
\text { Value }\end{array}$ & $\begin{array}{l}\text { Annual Mean } \\
\text { of HHI Values }\end{array}$ & $\begin{array}{l}\text { Annual Standart } \\
\text { Deviation of } \mathrm{HHI} \\
\text { Values }\end{array}$ \\
\hline \multirow{4}{*}{2014} & 1 & 0.07836 & \multirow{4}{*}{0.06346} & \multirow{4}{*}{0.01790} \\
\hline & 2 & 0.04942 & & \\
\hline & 3 & 0.07950 & & \\
\hline & 4 & 0.04657 & & \\
\hline \multirow{4}{*}{2015} & 1 & 0.09662 & \multirow{4}{*}{0.06695} & \multirow{4}{*}{0.03538} \\
\hline & 2 & 0.05698 & & \\
\hline & 3 & 0.09302 & & \\
\hline & 4 & 0.02116 & & \\
\hline \multirow{4}{*}{2016} & 1 & 0.08599 & \multirow{4}{*}{0.06568} & \multirow{4}{*}{0.03282} \\
\hline & 2 & 0.10114 & & \\
\hline & 3 & 0.03960 & & \\
\hline & 4 & 0.03600 & & \\
\hline \multirow{4}{*}{2017} & 1 & 0.07820 & \multirow{4}{*}{0.06316} & \multirow{4}{*}{0.01472} \\
\hline & 2 & 0.05563 & & \\
\hline & 3 & 0.04638 & & \\
\hline & 4 & 0.07243 & & \\
\hline \multirow{4}{*}{2018} & 1 & 0.04669 & \multirow{4}{*}{0.06364} & \multirow{4}{*}{0.02043} \\
\hline & 2 & 0.05157 & & \\
\hline & 3 & 0.06406 & & \\
\hline & 4 & 0.09225 & & \\
\hline
\end{tabular}

Table 2 designates that the company's real operating profits index values range between 0.02116 (2015 Q4) and 0.10114 (2016 Q2). It is also intriguing that the highest concentrations are achieved in the first and third quarters of 2014 and 2015 and moreover, 2016 and 2017 data reveal a similar pattern. It is possible that the company could be taking periodical precautions about its revenues and / or costs in relation to its base operations. The absence of such a pattern in 2018, on the other hand, could be a sign of a company policy change, a change in regulations or changes in national and / or international contingencies. 
INTERNATIONAL JOURNAL OF ACADEMIC RESEARCH IN BUSINESS AND SOCIAL SCIENCES Vol. 10, No. 2, Feb, 2020, E-ISSN: 2222-6990 (C) 2020 HRMARS

The graph of the index values in Table 2 along with the trend shows that the company engages in a steadier state of real operating profits (Figure 3), compared to its engagement in net foreign trade (Figure 2).

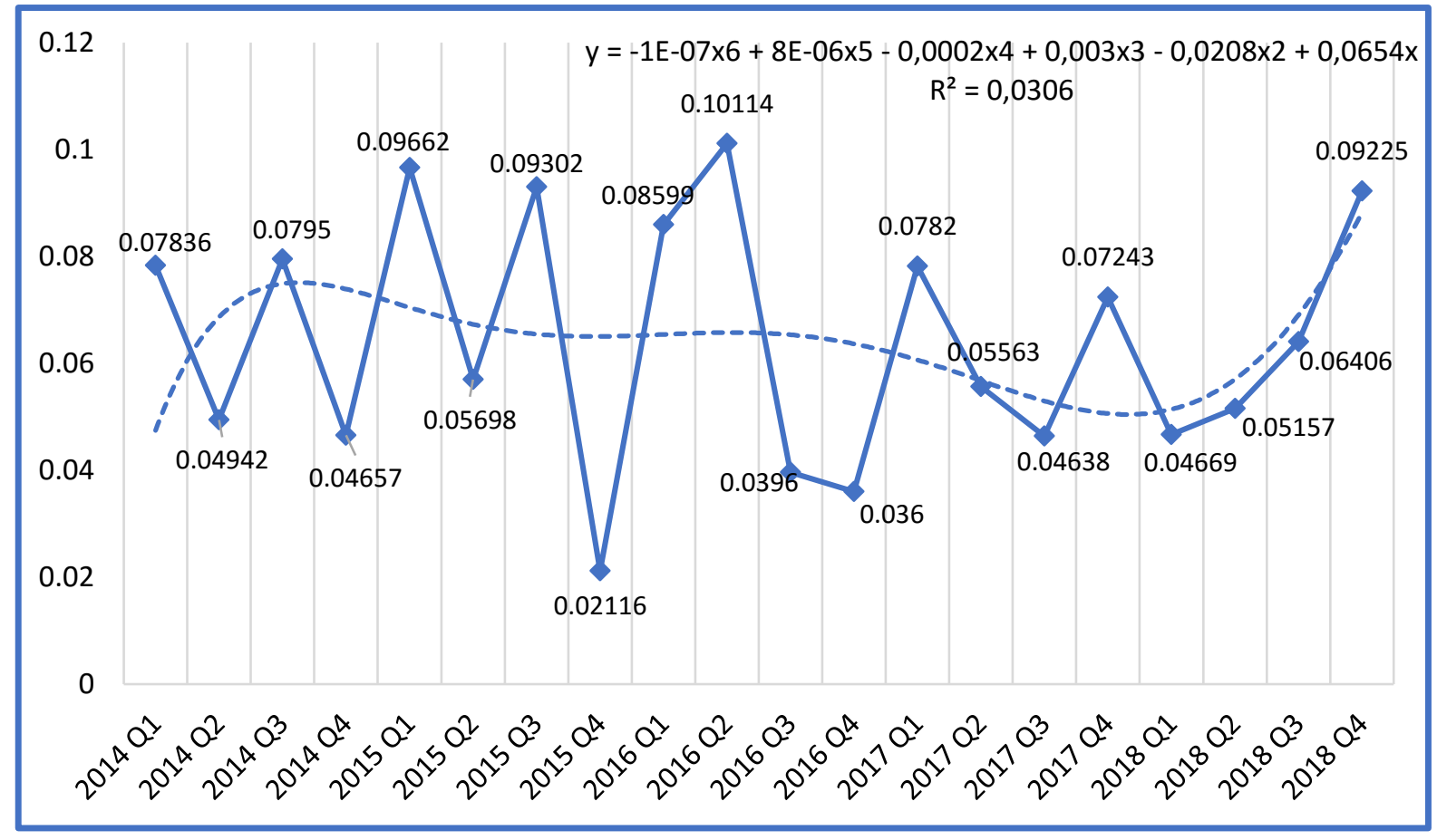

Figure 3. Real Operating Profits Concentration Trend

As per Figure 3, the overall trend shows a weak inclination of decline, similar to that of net foreign trade in Figure 2. Another similarity is about the volatilities in 2018; both trends show tremendous volatilities in this year, but the trend of real operating profits has a sharp increase while the net foreign trade concentration trend falls deeply (Figure 2).

\section{Research Model Analysis}

As the concentration index values are calculated, the last step is to check the results about the research model proposed in Figure 1. A linear regression analysis is run and the results are presented in Table 3. 
INTERNATIONAL JOURNAL OF ACADEMIC RESEARCH IN BUSINESS AND SOCIAL SCIENCES Vol. 10, No. 2, Feb, 2020, E-ISSN: 2222-6990 @ 2020 HRMARS

Table 3. Net Foreign Trade Concentration's Effect on Real Operating Profits Concentration

\begin{tabular}{|c|c|c|c|c|c|c|}
\hline \multicolumn{7}{|c|}{ Model Summary } \\
\hline Model & $\mathbf{R}$ & R Square & $\begin{array}{l}\text { Adjusted R } \\
\text { Square }\end{array}$ & $\begin{array}{l}\text { Std. Error of } \\
\text { the Estimate }\end{array}$ & & \\
\hline \multirow{11}{*}{1} & $0.084^{a}$ & 0.007 & -0.048 & 0.02336300 & & \\
\hline & \multicolumn{6}{|l|}{ ANOVA $^{b}$} \\
\hline & & $\begin{array}{l}\text { Sum of } \\
\text { Squares }\end{array}$ & df & Mean Square & $\mathbf{F}$ & Sig. \\
\hline & Regression & 0.000 & 1 & 0.000 & 0.128 & $0.725^{a}$ \\
\hline & Residual & 0.010 & 18 & 0.001 & & \\
\hline & Total & 0.010 & 19 & & & \\
\hline & \multicolumn{6}{|l|}{ Coefficients $^{\mathbf{b}}$} \\
\hline & & \multicolumn{2}{|c|}{$\begin{array}{l}\text { Unstandardized } \\
\text { Coefficients }\end{array}$} & $\begin{array}{l}\text { Standardized } \\
\text { Coefficients }\end{array}$ & & \\
\hline & & B & Std. Error & Beta & $\mathrm{t}$ & Sig. \\
\hline & (Constant) & 0.068 & 0.011 & & 6.028 & 0.000 \\
\hline & $\begin{array}{l}\text { Net Foreign } \\
\text { Trade } \\
\text { Concentration }\end{array}$ & -0.051 & 0.143 & -0.084 & -0.357 & 0.725 \\
\hline
\end{tabular}

Table 3 undoubtedly posits that the research model in Figure 1 is not valid under given circumstances. The company's net foreign trade concentration is not able to pose any effect on its real operating profits concentration ( $\mathrm{Sig}=0.725$; $\mathrm{Sig}>0.05$ ). In this case, the two ends must be considered seperately. This obvious result implies the possibility of other reasons' existence to account for when the issue is real operating profits concentration.

\section{Conclusion and Recommendations}

This study considers the performance of a pioneering drug company in Turkey and strives to figure out whether and how the two performance ends, namely foreign trade and profitability, are related if foreign trade performance is claimed to affect the profitability. For this purpose, the net foreign trade figures and real operating profits are calculated by paying attention to the necessity that these two are exactly limited to the products of the company. The calculated figures are then standardized and indexed, therefore concentrated, using the Hirschman-Herfindahl approach. Due to permissons taken from the company, January 2014-December 2018 period is taken into account.

An investigation of the two concentrations yields interesting results. The net foreign trade concentration has its biggest turbulance in 2018 with a peak in the beginning in the entire period under question, followed by a profound fall. This outcome, paired with very paralel results from annual means and standard deviations suggests that the company has some problems with its foreign trade in this particular year. The trade concentration trend implies a deviation from concentration - 
the company is in the process of scattering its foreign trade accounts among many different items related to its products.

Concentration index values of real operating profits reveal that there is a general pattern; these profits are usually more concentrated in the first and third quarters of almost all the years within the period considered, except for 2018. This urges the idea that 2018 could be a hard year not only in terms of foreign trade, but also in terms of profitability stabilization for the company. While another similarity reached when both ends are compared is the overall deviation from the respective concentration, a difference is the extent of steadiness. The company is able to keep its real operating profits more stable than its net foreign trade on an annual basis. It is considered that simultaneous contributions of national and international operations could be the cause of such an outcome as national context could be used to offset specific risks or variabilities of foreign context. A final difference between the two is the direction of change in 2018, this year brings forth a great deal of turbulance but the concentration of real operating profits has a sharp increase albeit there is a great fall in the net foreign trade concentration. Though there are similarities and differences between the two ends, there is no effect of net foreign trade concentration on the concentration of real operating profits. The most powerful expectation, in this case, is the possible existence of other factors in effect. One of such factors could be the dominance of national operations in financial terms within the company's real operating profits. It is also possible that the company could be exposed to great currency volatilities, which could reflect on its costs and / or revenues in the international context. A final factor could be the sole focus on the products; the company could be heavily engaging in other aspects with respect to its foreign trade such as research and development, investments, patents, and spare parts of machinery used.

There is a great room for further research. This study uses only one specific approach for calculation, but multiple concentration methods could be used and results could be compared in future studies. It is also possible that there could be comparisons among competitiors in specific sectors and markets in relation to the subject. There could also be enhancements in terms of the scope of performance ends considered and the research model.

There are also possible suggestions for company policies. The fluctuations in both ends require a greater dispersion related to items of the products. In other words, an appropriate foreign trade policy could be the expansion of trade span over more countries, and thus, becoming less vulnerable to unexpected events in each single country. The policy for revenues and costs related to products could also be changed. For instance, there could be a dynamic purchasing policy for products' items that considers changes in currencies, a larger item stock might be built up in advance to avoid potential future price increases, and the current technology may be upgraded to decrease costs of production. As seen, there are many choices for policy updates.

\section{References}

Adedeji, E. A. (2014). A Tool for Measuring Organization Performance Using Ratio Analysis. Advances in Social Sciences Research Journal, 1(8), 95-103.

Akal, Z. (2005). Measurement and Control of Performance in Businesses: Multifaceted Performance Indicators (In Turkish), National Productivity Center Publications No: 473, Ankara, Turkey.

Aliona, B. (2016). Financial Performance Measurement Tools. Annals of Economy Series, 3, 169-173. 
INTERNATIONAL JOURNAL OF ACADEMIC RESEARCH IN BUSINESS AND SOCIAL SCIENCES Vol. 10, No. 2, Feb, 2020, E-ISSN: 2222-6990 @ 2020 HRMARS

Alzgool, M. (2019). Nexus between Green HRM and Green Management towards Fostering Green Values. Management Science Letters, 9(12), 2073-2082.

Ayrancı, E. (2009). Measurement of Turkey's Globalization in Economic Terms and a Related Research (In Turkish). Journal of Anadolu Bil Vocational School, 4(16), 50-64.

Ayrancı, E. (2014). A Study on the Influence of Family on Family Business and Its Relationship to satisfaction with Financial Performance. E+ M Ekonomie a Management, 17(2), 87-105.

Baş, M. (2005). Market Concentration as a Factor that Affects Competition and Concentration Levels of Some Sectors in Turkey (In Turkish). Third Sector Cooperatives Journal, 148, 1-14.

Battal, M. Z. (2014). Concentration Levels of the Firms that Operate in Turkish Drug Sector and an Application. Master's thesis, Bayburt University, Bayburt, Turkey.

Bhamorasathit, S., \& Katawandee, P. (2014). Ratio Analysis of Publicly Traded Hotel Companies Listed on the Stock Exchange of Thailand (Set). ASBBS Proceedings, 21(1), 92-96.

Boddin, D., Raff, H., \& Trofimenko, N. (2017). Foreign Ownership and the Export and Import Propensities of Developing-Country Firms. The World Economy, 40(12), 2543-2563.

Caba, N. (2017). Effects of Financial Leverage and Firm Size on Financial Performance: An Application on the Businesses that are Traded in Istanbul Stock Exchange Industry Index (In Turkish). International Journal of Management, Economics and Business, 13(5), 796-811.

Campbell, K., \& Mínguez-Vera, A. (2008). Gender Diversity in the Boardroom and Firm Financial Performance. Journal of Business Ethics, 83(3), 435-451.

Chen, C. M., \& Chang, K. L. (2012). Diversification Strategy and Financial Performance in the Taiwanese Hotel Industry. International Journal of Hospitality Management, 31(3), 10301032.

Clement, J. P., McCue, M. J., Luke, R. D., Bramble, J. D., Rossiter, L., Ozcan, Y. A., \& Pai, C. W. (1997). Strategic Hospital Alliances: Impact on Financial Performance. Health Affairs, 16(6), 193-203.

Demirel, O. (2014). Market Power Research in Banking Sector in Turkey. Doctoral dissertation, Süleyman Demirel University, Isparta, Turkey.

Ertuğrul Ayrancl, A. (2018). New Financing Perspectives in terms of Innovative Entrepreneurship. In E. Ayrancı (Ed.), Innovativeness and Entrepreneurship: Approaches with Management, Marketing, and Finance Perspectives, Beta Publications, İstanbul, Turkey, pp. 187-213.

Evren, A., \& Bayer, Z. A. (2018). Herfindahl-Hirschmann and Similar Indexes that are Derivated from the Entropy Concept to be Used to Determine Market Concentration Levels (In Turkish). Journal of Applied Social Sciences, 2(1), 1-13.

Fosu, S. (2013). Capital Structure, Product Market Competition and Firm Performance: Evidence from South Africa. The Quarterly Review of Economics and Finance, 53(2), 140-151.

Gleason, K. C., Mathur, L. K., \& Mathur, I. (2000). The Interrelationship between Culture, Capital Structure, and Performance: Evidence from European Retailers. Journal of Business Research, 50(2), 185-191.

Ildırar, M., \& Kıral, E. (2018). Market Structure and Concentration: An Analysis on Turkish Automobile Sector (In Turkish). Journal of the Bolu Abant Izzet Baysal University Social Sciences Institute, 18(1), 93-117.

Jank, M. S., Leme, M. F. P., Nassar, A. M., \& Faveret Filho, P. (1999). Concentration and Internationalization of Brazilian Agribusiness Exporters. The International Food and Agribusiness Management Review, 2(3-4), 359-374. 
INTERNATIONAL JOURNAL OF ACADEMIC RESEARCH IN BUSINESS AND SOCIAL SCIENCES

Vol. 10, No. 2, Feb, 2020, E-ISSN: 2222-6990 @ 2020 HRMARS

Kaya, F. (2015). Foreign Trade Operations Management (In Turkish), Beta Publications, İstanbul, Turkey.

Kaynak, S. (2016). Competition Structure and Concentration Analysis of Turkish Drug Sector (In Turkish). Journal of the Çankırı Karatekin University FEAS, 6(2), 49-66.

Khalid, N., Islam, D. M. Z., \& Ahmed, M. R. M. (2019). Sentrepreneurial Training and Organizational Performance: Implications for Future. Humanities \& Social Sciences Reviews, 7(2), 590-593.

Kostakoğlu, S. F. (2015). Concentration Analysis towards Internet Service Providers (In Turkish). International Journal of Management, Economics, and Business, 11(25), 129-140.

Krivka, A. (2016). On the Concept of Market Concentration, the Minimum Herfindahl-Hirschman Index, and its Practical Application, Panoeconomicus, 63(5), 525-540.

Küçükkiremitçi, O., Karaca, M. E., \& Eşiyok, B. A. (2010). Core Markets, Countries, Competitors, and Competitiveness in the Prominent Sectors within Turkey's Exports (In Turkish), Türkiye Kalkınma Bankası Publications, Ankara, Turkey.

Melwani, R., \& Sitlani, M. (2019). Study of Financial Performance and Its Determinants: Empirical Evidence from Listed Indian 2/3 Wheeler Manufacturer Firms. In Proceedings of 10th International Conference on Digital Strategies for Organizational Success, Available at SSRN 3308728.

Minichilli, A., Brogi, M., \& Calabrò, A. (2016). Weathering the Storm: Family Ownership, Governance, and Performance through the Financial and Economic Crisis. Corporate Governance: An International Review, 24(6), 552-568.

Muhammad, K., Saoula, O., Issa, M., \& Ahmed, U. (2019). Contract Management and Performance Characteristics: An Empirical and Managerial Implication for Indonesia. Management Science Letters, 9(8), 1289-1298.

Nuhu, M. (2014). Role of Ratio Analysis in Business Decisions: A Case Study NBC Maiduguri Plant. Journal of Educational and Social Research, 4(5), 105-118.

Oyman, M. (2002). Importance of Loyalty Programs to Provide Customer Loyalty (In Turkish). Kurgu Journal, 19(19), 169-185.

Pehlivanoğlu, F., \& Tekçe, E. (2013). Concentration Analysis via Herfindahl-Hirschman and CRm Indexes in Turkish Electricity Sector (In Turkish). Journal of the Bolu Abant Izzet Baysal University Social Sciences Institute, 28(28), 363-386.

Pindyuk, O. (2008). Ukraine: Foreign Trade and Industrial Restructuring. In O. Pindyuk (Ed.), Economic Restructuring and Integration in Eastern Europe, Nomos Verlagsgesellschaft mbH \& Co. KG., Germany, pp. 193-218.

Roj, J. (2016). Competition Measurement of Hospitals in Poland: The Herfindahl-Hirschman Index Approach, Ekonomika (Economics), 95(1), 166-181.

Sarkodie, E. E., Addai, I., \& Asiedu, D. K. (2015). Financial Ratios (Accounting Ratios) and Survival of Microfinance Institutions in Ghana. Journal of Business and Financial Affairs, 4(151), 21672169.

Tennyson, D. H., \& Fottler, M. D. (2000). Does System Membership Enhance Financial Performance in Hospitals? Medical Care Research and Review, 57(1), 29-50.

Wang, D., \& Zhou, F. (2016). The Application of Financial Analysis in Business Management. Open Journal of Business and Management, 4(3), 471-475. 
INTERNATIONAL JOURNAL OF ACADEMIC RESEARCH IN BUSINESS AND SOCIAL SCIENCES

Vol. 10, No. 2, Feb, 2020, E-ISSN: 2222-6990 @ 2020 HRMARS

Wang, T., Wang, Y., \& McLeod, A. (2018). Do Health Information Technology Investments Impact Hospital Financial Performance and Productivity? International Journal of Accounting Information Systems, 28, 1-13.

Wingard, H. C., \& Vorster, Q. (2001). Financial Performance of Environmentally Responsible South African Listed Companies. Meditari Accountancy Research, 9, 313-332.

Yahaya, Y., Oloko Magret, A., \& Oluoch, O. (2017). The Relationship between Foreign Trade and Financial Performance of the Listed Manufacturing Companies in Nigeria. IOSR Journal of Business and Management, 19(2), 65-72.

Yaşar, M., \& Gerede, E. (2018). Identifying the Market Structure by Market Concentration Measures in Turkish Domestic Airline City Pair Markets (In Turkish). CBU, Journal of Management and Economics, 25(1), 171-197.

Yaşar, M., Kiracı, K., Kayhan, S., \& Ustaömer, T. C. (2017). A Concentration Analysis in the Turkish Domestic Air Transportation Industry Using CRm and Herfindahl-Hirschman Indexes, Gaziantep University Journal of Social Sciences, 16(3), 687-704. 